\title{
Effect of some Plant Extracts and Oils on Yield and Fruit Quality of Naomi Mango Cultivar
}

\author{
EL-Sayed Mostafa Qaoud \\ Horticultural Department, Faculty of Agriculture, Suez Canal University
}

Received: $18 / 12 / 2019$

\begin{abstract}
Five plant extracts and oils namely green tea extract, turmeric extract, black seed oil, onion oil and garlic oil each at $2 \%$ were tested for evaluating their effect on yield and fruit quality of the Naomi Mango trees, during $2017-$ 2018 seasons, these extracts were sprayed two times, one at full bloom and second at pea stage. The plant extract improve all physical and chemical characters, respectively. Turmeric extract, onion oil and garlic oil were more effective to improve tree yield, fruit shape, firmness, gave the best red color and decreased the enzyme activities. Green tea extract increased vitamin $\mathrm{C}$ and total phenols. Black seed oil increased fruit acidity percentage and showed the lowest ratio of TSS/ TA. Generally, foliar sprays of plant extracts and oils improved fruit quality and help in delay fruit ripening, which is important in fruit marketing.
\end{abstract}

Keywords: Mango, Naomi, plant extracts, oils, yield, fruit quality

\section{INTRODUCTION}

Many problems face mango producers such as low fruit set $\%$ and high fruit drop $\%$ at different growth stages, moreover, most mango cvs are very sensitive to the fluctuation in climatic conditions particularly during blooming stage thus the trees fail to produce satisfactory yield (Habib et al.,2004). Since ancient times, plant extracts were used in many ways, recently public health and environmental safety concerns encouraged the use of these natural products as complete replacement of chemicals for improving growth (Faissal et al., 2014). All plant extracts had an obvious effect on controlling various disorders (Srivastava and Lal, 1997). Turmeric contains curcuminiods, essential oils and plant pigments (Srimal, 1997; Ammon and Wehle, 1999). Green tea extract contains different tannins, vitamins, antioxidants and minerals. Green tea products mainly contain tea polyphenols, which are natural antioxidants and have been demonstrated to show ant oxidative, anti-carcinogenic and antimicrobial properties by many researchers (McKay and Blumberg, 2002; Rietveld and Wiseman, 2003; Aroyeun and Jayeola 2016). The higher own contents of onion and garlic oils from volatile compounds and sulfur compounds put both in the top for their essential roles on fruiting of fruit crops (Bruneton, 2001; Parakash and Majeed, 2003; Pons, 2003). Black seed oil is a product of Nigella sativa plant, which is native to Asia; $N$. sativa seed contains more than $30 \%$ fixed oil and 0.4 to $0.45 \%$ volatile oil (Nergiz and Otles, 1993). Thymoquinone (TQ) is an abundant component of black seed oil extract (Ghosheh et al., 1999). TQ has a strong antioxidant potential due to its free radicals scavenging activity (Hosseinzadeh et al., 2007).

Plant extracts were found by many authors to enhance growth, nutritional status, yield and fruit quality of fruit crops (Obagwu et al., 1997; Paik and Chung, 1997; Okigbo and Emoghene, 2003; Chawdhury et al., 2007; El-Shayeb 2009; Bhdwaj et al., 2010; Abd El- Rahman and El- Masry, 2012; Ahmed et al., 2013; Mohamed and Mohamed, 2013;
Faissal et al., 2014; Eid et al., 2018; Kahramanoglu et al., 2018; El-Rokiek et al., 2019).

The aim of this study was undertaken to find out a suitable plant extract and oil to improve the yield and fruit quality of Naomi mango cultivar.

\section{MATERIALS AND METHODS}

This study was conducted during 2017 and 2018 seasons on 5 years old of Naomi Mango trees in a private orchard at Al-Salehia region, El- Sharkia governorate. The trees were planted at $2 \times 5$ meters a part in sandy soil under drip irrigation system using Nile water.

This study included the following treatments:

Control (trees sprayed with tap water)

Spraying green tea extract at $2 \%$

Spraying turmeric extract at $2 \%$

Spraying black seed oil at $2 \%$

Spraying onion oil at $2 \%$

Spraying garlic oil at $2 \%$

Each treatment was replicated three times, one tree per each; two plant extracts green tea extract and turmeric extract and three oil extracts black seed oil, onion oil and garlic oil these extracts were sprayed two times, at full bloom and at pea stage.

\section{Data recorded:}

Yield: At harvesting time (middle of August), number of fruits per tree and yield as $(\mathrm{Kg} /$ tree) were recorded.

\section{Fruit physical and chemical properties:}

A representative sample of 15 mature fruits was taken from each replicate for determination the following fruit properties.

Fruit physical properties: Fruit, peel, seed and pulp weight (g.), net ratio \%, fruit length, width and thickness $(\mathrm{cm})$, fruit shape and firmness $(\mathrm{N})$.

Fruit color according to color index (CI) was calculated to Jimenez-Cuesta et al. (1981) as follows: $(\mathrm{CI}=1000 \times \mathrm{a} / \mathrm{L} \times \mathrm{b})$ where $(\mathrm{L}=$ lightness; $\mathrm{a}=$ values on green to red scale; $b=$ values on blue to yellow scale). 


\section{Fruit chemical properties:}

Total soluble solids (\%), total acidity (\%), TSS/Acid ratio, VC (mg/100 g fresh weight), Sugars (total, reducing and non - reducing sugars \%) and total phenols (mg/100 g fresh weight) according to A.O.A.C (2000).

Some fruit Enzymes activity; Polyphenol oxidase (PPO) and Peroxidase, (POD).

\section{Preparation of Enzyme Extracts (PPO, POD):}

The enzymatic crude extract was prepared according to the method of (Trejo-Márquez et al., 2010), Mango pulp or peel tissues (200 mg) were homogenized in a mortar with liquid $\mathrm{N}_{2}$. The homogenates were mixed with $1 \mathrm{ml}$ of $0.2 \mathrm{M}$ sodium phosphate buffer ( $\mathrm{pH} 7.0$ ) and centrifuged for $15 \mathrm{~min}$ at $14000 \mathrm{~g}$ during and $4^{\circ} \mathrm{C}$. The supernatant was extracted and the activity of each enzyme was determined.

\section{Enzyme Assay (PPO, POD):}

PPO activity was determined at $420 \mathrm{~nm}$ and $40^{\circ} \mathrm{C}$. The reaction mixtures contained aliquots $(100$ $\mu \mathrm{l})$ of enzyme extracts, $1.45 \mathrm{ml} 0.07 \mathrm{mM}$ dopamine solution in $10 \mathrm{mM}$ sodium phosphate buffer ( $\mathrm{pH} 7.5)$. Enzyme activity was expressed as $\Delta \mathrm{A} 420 \mathrm{~min}-1 \mathrm{mg}$ protein-1.

POD activity was measured at $485 \mathrm{~nm}$. The reaction mixtures contained $1.35 \mathrm{ml} 0.05 \mathrm{M}$ sodium phosphate buffer ( $\mathrm{pH} 5.0$ ), $100 \mu \mathrm{l}$-phenylenediamine $(10 \mathrm{~g} / \mathrm{ml}), 50 \mu \mathrm{l}$ of hydrogen peroxide solution $(15 \mathrm{ml}$ $\mathrm{L}-1)$ and $100 \mu \mathrm{l}$ of enzyme extract at $60^{\circ} \mathrm{C}$ and $30^{\circ} \mathrm{C}$, for peel and pulp, respectively. Enzyme activity was expressed as $\Delta \mathrm{A} 420 \mathrm{~min}-1 \mathrm{mg}$ protein-1.

\section{Statistical analysis:}

Data recorded in all seasons were subjected to analysis of variance according to Snedecor and Cochran (1990) and L.S.D test was used to differentiate means using the MSTAT-C statistical Package (MSTAT-C, 1990).

\section{RESULTS AND DISCUSSION}

\section{Fruit physical properties:}

Concerning the effect of some plant extracts and oils treatments on yield of Naomi mango, data in Table (1) illustrated that in both seasons it gave a significantly increased in the number of fruits/tree and yield/tree ( $\mathrm{kg})$ especially with turmeric extract treatment than with onion oil. Data in Table (2) showed that all plant extracts increased fruit weight and pulp weight than control. The garlic oil was the most effective in increasing net ratio percentage than turmeric extract. Table (3) indicted that treatment with turmeric extract improved fruit shape and firmness then onion oil and garlic oil. Table (4) showed that all plant extracts improved seed character than control, and spraying with green tea extract improve all seed characters than Garlic oil, onion oil and black seed oil, respectively. These results are in agreement with those obtained by Faissal et al. (2014) who suggested that spraying Keitte mango trees three times with the four plant extracts (onion, garlic, green tea and turmeric) each at $0.1 \%$ and / or SA at $100 \mathrm{ppm}$ was significantly responsible for improving yield and number of fruits per tree over the check treatment. Also, El-wasfy et al. (2013) stated that turmeric extract occupied the first position followed by garlic and onion oil in improving yield of orange trees. Kahramanoğlu (2018) indicated that black seed oil application has considerable effects on the postharvest quality of pomegranates. Both black seed oil and propolis treatments significantly affected the maintenance of pomegranate fruit weight, juice content and visual quality (Kahramanoglu et al., 2018). El-Rokiek et al. (2019) concluded that spraying quinoa plants with natural clove extract of garlic or leaf extract increased growth and yield of eucalyptus.

Table (1): Effect of spraying some plant extracts and oils on number of fruits per tree and Yield (Kg/tree) of Naomi mango cv during 2017 \& 2018 seasons

\begin{tabular}{|c|c|c|c|c|}
\hline \multirow{2}{*}{ Treatment } & \multicolumn{2}{|c|}{ Number of Fruits/tree } & \multicolumn{2}{|c|}{ Yield (Kg/tree) } \\
\hline & 2017 & 2018 & 2017 & 2018 \\
\hline Control & $35.00 \mathrm{c}$ & $33.5 \mathrm{c}$ & $24.95 \mathrm{e}$ & $23.88 \mathrm{~d}$ \\
\hline Green Tea Extract 2\% & $28.50 \mathrm{~d}$ & $29.00 \mathrm{~d}$ & $27.16 \mathrm{de}$ & $27.62 \mathrm{~cd}$ \\
\hline Turmeric Extract 2\% & $53.50 \mathrm{a}$ & $51.00 \mathrm{a}$ & $40.35 \mathrm{a}$ & $38.46 \mathrm{a}$ \\
\hline Black Seed Oil 2\% & $33.00 \mathrm{c}$ & $32.00 \mathrm{~cd}$ & $29.28 \mathrm{~cd}$ & $28.38 \mathrm{c}$ \\
\hline Onion Oil 2\% & $42.50 \mathrm{~b}$ & $41.50 \mathrm{~b}$ & $34.03 \mathrm{~b}$ & $33.21 \mathrm{~b}$ \\
\hline Garlic Oil 2\% & $32.00 \mathrm{~cd}$ & $32.00 \mathrm{~cd}$ & $31.37 \mathrm{bc}$ & $31.39 \mathrm{bc}$ \\
\hline
\end{tabular}


Table (2): Effect of spraying some plant extracts and oils on fruit, peel, seed and pulp weight (g) and net ratio \%, of Naomi mango cv during 2017 \& 2018 seasons

\begin{tabular}{|c|c|c|c|c|c|c|c|c|c|c|}
\hline \multirow{2}{*}{ Treatment } & \multicolumn{2}{|c|}{ Fruit weight (g) } & \multicolumn{2}{|c|}{ Peel weight (g) } & \multicolumn{2}{|c|}{ Seed weight (g) } & \multicolumn{2}{|c|}{ Pulp weight (g) } & \multicolumn{2}{|c|}{ Net ratio $\%$} \\
\hline & 2017 & 2018 & 2017 & 2018 & 2017 & 2018 & 2017 & 2018 & 2017 & 2018 \\
\hline Control & $712.55 \mathrm{f}$ & $730.00 \mathrm{f}$ & $97.00 \mathrm{c}$ & $97.75 \mathrm{c}$ & $38.85 \mathrm{c}$ & $39.40 \mathrm{c}$ & $576.70 \mathrm{e}$ & $592.85 \mathrm{e}$ & $80.93 \mathrm{~b}$ & $81.21 \mathrm{c}$ \\
\hline $\begin{array}{l}\text { Green Tea } \\
\text { Extract } 2 \%\end{array}$ & $952.7 \mathrm{~b}$ & $960.00 \mathrm{~b}$ & $141.40 \mathrm{a}$ & $140.00 \mathrm{a}$ & $52.00 \mathrm{a}$ & $51.00 \mathrm{a}$ & $759.30 \mathrm{~b}$ & $769.00 \mathrm{~b}$ & $79.7 \mathrm{bc}$ & $80.11 \mathrm{~d}$ \\
\hline $\begin{array}{l}\text { Turmeric } \\
\text { Extract } 2 \%\end{array}$ & $754.00 \mathrm{e}$ & $752.5 \mathrm{e}$ & $76.6 \mathrm{e}$ & $73.30 \mathrm{e}$ & $36.95 \mathrm{c}$ & $38.25 \mathrm{c}$ & $640.45 \mathrm{~d}$ & $640.95 \mathrm{~d}$ & $84.94 \mathrm{a}$ & $85.18 \mathrm{~b}$ \\
\hline $\begin{array}{l}\text { Black Seed } \\
\text { Oil } 2 \%\end{array}$ & $886.85 \mathrm{c}$ & $890.00 \mathrm{c}$ & $141.25 \mathrm{a}$ & $144.00 \mathrm{a}$ & $51.65 \mathrm{a}$ & $52.00 \mathrm{a}$ & $693.95 \mathrm{c}$ & $694.00 \mathrm{c}$ & $78.25 \mathrm{c}$ & $77.98 \mathrm{f}$ \\
\hline Onion Oil 2\% & $800.30 \mathrm{~d}$ & $807.00 \mathrm{~d}$ & $120.90 \mathrm{~b}$ & $121.80 \mathrm{~b}$ & $46.90 \mathrm{~b}$ & $47.40 \mathrm{~b}$ & $632.50 \mathrm{~d}$ & $637.80 \mathrm{~d}$ & $79.03 \mathrm{c}$ & $79.03 \mathrm{e}$ \\
\hline Garlic Oil 2\% & $979.95 \mathrm{a}$ & $977.50 \mathrm{a}$ & $86.75 \mathrm{~d}$ & $86.50 \mathrm{~d}$ & $47.30 \mathrm{~b}$ & $46.85 \mathrm{~b}$ & $845.90 \mathrm{a}$ & $844.15 \mathrm{a}$ & $86.32 \mathrm{a}$ & $86.36 \mathrm{a}$ \\
\hline
\end{tabular}

Means having the same letter (s) within the same column and row are not significantly different according to Duncan, $\mathrm{s}$ multiple range test at $5 \%$ level of probability

Table (3): Effect of spraying some plant extracts and oils on fruit length, width, thickness (cm) fruit shape and firmness (N) of Naomi mango cv during 2017 \& 2018 seasons

\begin{tabular}{|c|c|c|c|c|c|c|c|c|c|c|}
\hline \multirow{2}{*}{ Treatment } & \multicolumn{2}{|c|}{$\begin{array}{l}\text { Fruit length } \\
(\mathbf{c m})\end{array}$} & \multicolumn{2}{|c|}{ Fruit width (cm) } & \multicolumn{2}{|c|}{ Fruit shape } & \multicolumn{2}{|c|}{$\begin{array}{l}\text { Fruit thickness } \\
\text { (cm) }\end{array}$} & \multicolumn{2}{|c|}{$\begin{array}{l}\text { Fruit firmness } \\
\text { (N) }\end{array}$} \\
\hline & 2017 & 2018 & 2017 & 2018 & 2017 & 2018 & 2017 & 2018 & 2017 & 2018 \\
\hline Control & $12.74 b$ & $12.74 \mathrm{e}$ & $8.33 \mathrm{~b}$ & $8.31 \mathrm{~b}$ & $1.53 \mathrm{c}$ & $1.53 \mathrm{c}$ & $7.12 \mathrm{c}$ & $7.12 \mathrm{e}$ & $20.58 \mathrm{~d}$ & $20.62 \mathrm{e}$ \\
\hline $\begin{array}{l}\text { Green Tea } \\
\text { Extract } 2 \%\end{array}$ & $14.14 \mathrm{a}$ & $14.15 \mathrm{c}$ & $9.06 \mathrm{a}$ & $8.97 \mathrm{a}$ & $1.56 \mathrm{bc}$ & $1.58 \mathrm{~b}$ & $7.63 \mathrm{a}$ & $7.71 \mathrm{~b}$ & $23.89 \mathrm{bc}$ & $23.97 \mathrm{c}$ \\
\hline $\begin{array}{l}\text { Turmeric } \\
\text { Extract } 2 \%\end{array}$ & $12.82 \mathrm{~b}$ & $12.79 \mathrm{e}$ & $7.79 \mathrm{c}$ & $7.88 \mathrm{c}$ & $1.65 \mathrm{a}$ & $1.62 \mathrm{a}$ & $6.76 \mathrm{~d}$ & $7.81 \mathrm{a}$ & $26.46 \mathrm{a}$ & $26.33 \mathrm{a}$ \\
\hline $\begin{array}{l}\text { Black Seed } \\
\text { Oil } 2 \%\end{array}$ & $12.87 \mathrm{~b}$ & $12.94 \mathrm{~d}$ & $9.06 \mathrm{a}$ & $9.01 \mathrm{a}$ & $1.42 \mathrm{~d}$ & $1.44 \mathrm{~d}$ & $7.37 \mathrm{~b}$ & $7.39 \mathrm{~d}$ & $22.91 \mathrm{c}$ & $22.89 \mathrm{~d}$ \\
\hline Onion Oil 2\% & $14.33 \mathrm{a}$ & $14.36 \mathrm{a}$ & $9.02 \mathrm{a}$ & $9.00 \mathrm{a}$ & $1.59 \mathrm{~b}$ & $1.60 \mathrm{~b}$ & $7.35 \mathrm{~b}$ & $7.39 \mathrm{~d}$ & $24.13 \mathrm{bc}$ & $24.39 \mathrm{~b}$ \\
\hline Garlic Oil 2\% & $14.17 \mathrm{a}$ & $14.26 \mathrm{~b}$ & $9.09 \mathrm{a}$ & $9.02 \mathrm{a}$ & $1.56 \mathrm{bc}$ & $1.58 \mathrm{~b}$ & $7.61 \mathrm{a}$ & $7.57 \mathrm{c}$ & $25.36 \mathrm{ab}$ & $24.44 \mathrm{~b}$ \\
\hline
\end{tabular}

Means having the same letter (s) within the same column and row are not significantly different according to Duncan, $s$ multiple range test at $5 \%$ level of probability

Table (4): Effect of spraying some plant extracts and oils on seed length, width and thickness (cm) and seed shape of Naomi mango cv during 2017 \& 2018 seasons

\begin{tabular}{lcccccccc}
\hline & \multicolumn{2}{c}{ Seed Length (cm) } & Seed Width (cm) & \multicolumn{2}{c}{ Seed Shape } & \multicolumn{2}{c}{ Seed thickness (cm) } \\
\cline { 2 - 9 } Treatment & $\mathbf{2 0 1 9}$ & $\mathbf{2 0 1 8}$ & $\mathbf{2 0 1 9}$ & $\mathbf{2 0 1 8}$ & $\mathbf{2 0 1 7}$ & $\mathbf{2 0 1 8}$ & $\mathbf{2 0 1 7}$ & $\mathbf{2 0 1 8}$ \\
\hline Control & $9.71 \mathrm{~d}$ & $9.84 \mathrm{e}$ & $3.65 \mathrm{~b}$ & $3.71 \mathrm{c}$ & $2.66 \mathrm{bc}$ & $2.65 \mathrm{~d}$ & $1.35 \mathrm{~d}$ & $1.36 \mathrm{~d}$ \\
Green Tea Extract 2\% & $10.78 \mathrm{a}$ & $10.98 \mathrm{a}$ & $3.82 \mathrm{a}$ & $3.80 \mathrm{~b}$ & $2.83 \mathrm{a}$ & $2.89 \mathrm{a}$ & $1.68 \mathrm{a}$ & $1.66 \mathrm{a}$ \\
Turmeric Extract 2\% & $9.70 \mathrm{~d}$ & $9.80 \mathrm{e}$ & $3.46 \mathrm{c}$ & $3.46 \mathrm{~d}$ & $2.81 \mathrm{a}$ & $2.83 \mathrm{~b}$ & $1.51 \mathrm{c}$ & $1.52 \mathrm{c}$ \\
Black Seed Oil 2\% & $10.03 \mathrm{c}$ & $10.16 \mathrm{~d}$ & $3.85 \mathrm{a}$ & $3.83 \mathrm{ab}$ & $2.61 \mathrm{c}$ & $2.66 \mathrm{~d}$ & $1.56 \mathrm{bc}$ & $1.61 \mathrm{ab}$ \\
Onion Oil 2\% & $10.41 \mathrm{~b}$ & $10.41 \mathrm{c}$ & $3.73 \mathrm{ab}$ & $3.73 \mathrm{c}$ & $2.80 \mathrm{ab}$ & $2.79 \mathrm{bc}$ & $1.63 \mathrm{ab}$ & $1.56 \mathrm{bc}$ \\
Garlic Oil 2\% & $10.28 \mathrm{~b}$ & $10.74 \mathrm{~b}$ & $3.79 \mathrm{ab}$ & $3.86 \mathrm{a}$ & $2.72 \mathrm{abc}$ & $2.78 \mathrm{c}$ & $1.63 \mathrm{ab}$ & $1.63 \mathrm{ab}$ \\
\hline
\end{tabular}

Means having the same letter (s) within the same column and row are not significantly different according to Duncan, $s$ multiple range test at $5 \%$ level of probability 


\section{2- Fruit color:}

Table (5) indicated that turmeric extract gave the best red color and high color index than other treatments and that important because of Naomi mango is colorful fruit and generally attend to be read color when it became ripe.

\section{3- Fruit chemical properties:}

Spraying with plant extract specially garlic oil decreased fruit TSS than control and that delays fruit ripe and that important in fruit marketing (Table 6). Spraying with plant extract has no significantly different between all extracts and show increases in $\mathrm{TA} \%$ than control and that help in delays fruit ripe and that important in fruit marketing. The treatment with black seed oil and garlic oil showed the best ratio of TSS/TA than other plant extracts. Chowdhury et al. (2007) found that extracts from garlic improved number of fruits, TSS and yield of Ub'a mango trees.

Spraying plant extract generally increased fruit content of vitamin $\mathrm{C}$, using green tea extract than onion oil recorded the highest fruit content of vitamin C (Table 6). While Samad et al. (2019) showed that the showed that the maximum vitamin $\mathrm{C}$ content in china lime fruits was recorded in the fruits treated with garlic extracts, followed by ginger extract, whereas minimum vitamin $\mathrm{C}$ was observed in untreated fruits.

Spraying with plant extracts generally decreased the total and non-reducing sugars and increased the reducing sugars than control especially, garlic oil Table (7). Decrease total sugars prevent fruit from rapid deterioration and that important in fruit marketing. Garlic also contains vitamins, minerals, flavonoids, ascorbic acid, sulfur and trace of iodine. Seventeen amino acids are found in garlic, including eight essential ones. Effect of garlic extract on plant characters has been interpreted by El-Shayeb (2009).

Spraying with green tea extract showed highest content of total phenols Table (7). The action of phenolic compounds in foods has been drawn a lot of attention because of their biological activity in cancer and heart diseases prevention. These compounds are preferably oxidized in biological medium and function as antioxidant nutrient economizer, protecting organisms against the oxidative stress (Bravo, 1998). The analyzed mango cultivars contain expressive total phenolic concentrations that may contribute to increase antioxidant intake in human diet, since the intake of polyphenol compounds in the diet was estimated to range between 0.15 and $1.0 \mathrm{~g} /$ day (Scalbert and Williamson, 2000; Stahl et al., 2002). Rocha et al. (2007) reported that total phenolics content was different among four mango cultivars, being higher in Ub'a mango pulp. The polyphenol content of mango is high at the early part of the growth, which decreases during the ripe stage and remains fairly steady (Lakshminarayana et al., 1970). The loss of astringency in the course of ripening is associated with the loss of phenolic content (Selvaraj and Kumar, 1989). El-Sharony et al. (2015) indicated that, spraying plants extracts had an obvious effect on enhance the fruit chemical properties of mango cv Fagri Kalan. However, there were no significant effects of different treatments on mango fruit content of total acidity in both seasons.

\section{4- Enzymes Activity:}

Spraying with plant extract especially Turmeric Extract decreased the enzymes activity PPO and POD in fruit than control Table (8) and that delays fruit ripe and that important in fruit marketing. Reddy and Srivastava (2003) indicated that antioxidant enzymes like superoxide dismutase (SOD) and peroxidase (POD) were noticed to be very high at mature green stage, which significantly declined as the ripening proceeded. These antioxidant enzymes exhibited higher activity in the epicarp over mesocarp at all the stages of ripening. Venkatesan and Tamilmani (2010) investigated the effect of ethrel on the ripening of offseason fruits of Mangifera indica L. var. Neelum and they found that, the phenols decreased during ripening, both in the treated and control fruits. On the other hand, the activity of peroxidase, polyphenoloxidase and catalase increased. Polyphenoloxidase activity generally declined in the course of ripening in several Indian varieties including the 'Alphonso' (Selvaraj and Kumar, 1989).

Table (5): Effect of spraying some plant extracts and oils on fruit color of Naomi mango cv during 2017 \& 2018 seasons

\begin{tabular}{lccccccccc}
\hline & \multicolumn{7}{c}{ Fruit Color } \\
\cline { 2 - 10 } Treatment & \multicolumn{2}{c}{ L } & \multicolumn{2}{c}{ a } & \multicolumn{2}{c}{ b } & \multicolumn{2}{c}{ Index } \\
\cline { 2 - 10 } & $\mathbf{2 0 1 7}$ & $\mathbf{2 0 1 8}$ & $\mathbf{2 0 1 7}$ & $\mathbf{2 0 1 8}$ & $\mathbf{2 0 1 7}$ & $\mathbf{2 0 1 8}$ & $\mathbf{2 0 1 7}$ & $\mathbf{2 0 1 8}$ \\
\hline Control & $43.19 \mathrm{~b}$ & $43.71 \mathrm{~b}$ & $23.20 \mathrm{~b}$ & $23.07 \mathrm{~b}$ & $30.12 \mathrm{c}$ & $30.04 \mathrm{c}$ & $17.84 \mathrm{~b}$ & $17.57 \mathrm{c}$ \\
Green Tea Extract 2\% & $41.54 \mathrm{bc}$ & $41.60 \mathrm{~d}$ & $18.54 \mathrm{~d}$ & $18.12 \mathrm{e}$ & $31.18 \mathrm{~b}$ & $31.17 \mathrm{~b}$ & $14.32 \mathrm{~d}$ & $13.98 \mathrm{e}$ \\
Turmeric Extract 2\% & $43.73 \mathrm{ab}$ & $43.25 \mathrm{c}$ & $24.79 \mathrm{a}$ & $24.84 \mathrm{a}$ & $26.03 \mathrm{e}$ & $26.00 \mathrm{f}$ & $21.79 \mathrm{a}$ & $22.09 \mathrm{a}$ \\
Black Seed Oil 2\% & $45.99 \mathrm{a}$ & $45.99 \mathrm{a}$ & $16.68 \mathrm{e}$ & $17.00 \mathrm{f}$ & $32.69 \mathrm{a}$ & $32.71 \mathrm{a}$ & $11.10 \mathrm{e}$ & $11.30 \mathrm{f}$ \\
Onion Oil 2\% & $39.93 \mathrm{c}$ & $39.47 \mathrm{e}$ & $20.88 \mathrm{c}$ & $21.04 \mathrm{c}$ & $28.74 \mathrm{~d}$ & $28.94 \mathrm{e}$ & $18.21 \mathrm{~b}$ & $18.42 \mathrm{~b}$ \\
Garlic Oil 2\% & $43.57 \mathrm{ab}$ & $43.83 \mathrm{~b}$ & $20.14 \mathrm{c}$ & $20.21 \mathrm{~d}$ & $29.36 \mathrm{~cd}$ & $29.86 \mathrm{~d}$ & $15.75 \mathrm{c}$ & $15.44 \mathrm{~d}$ \\
\hline
\end{tabular}

Means having the same letter (s) within the same column and row are not significantly different according to Duncan, $\mathrm{s}$ multiple range test at $5 \%$ level of probability 
Table (6): Effect of spraying some plant extracts and oils on some chemical properties of Naomi mango cv during 2017 \& 2018 seasons

\begin{tabular}{lcccccccc}
\hline \multirow{2}{*}{ Treatment } & \multicolumn{2}{c}{ TSS } & \multicolumn{2}{c}{ TA \% } & \multicolumn{2}{c}{ TSS/TA } & \multicolumn{2}{c}{$\begin{array}{c}\text { VC (mg/100 g } \\
\text { fresh weight) }\end{array}$} \\
\cline { 2 - 9 } & $\mathbf{2 0 1 7}$ & $\mathbf{2 0 1 8}$ & $\mathbf{2 0 1 7}$ & $\mathbf{2 0 1 8}$ & $\mathbf{2 0 1 7}$ & $\mathbf{2 0 1 8}$ & $\mathbf{2 0 1 7}$ & $\mathbf{2 0 1 8}$ \\
\hline Control & $17.80 \mathrm{a}$ & $17.50 \mathrm{a}$ & $0.080 \mathrm{~b}$ & $0.080 \mathrm{c}$ & $231.77 \mathrm{a}$ & $218.77 \mathrm{a}$ & $27.60 \mathrm{f}$ & $28.55 \mathrm{e}$ \\
Green Tea Extract 2\% & $16.90 \mathrm{~b}$ & $17.10 \mathrm{~b}$ & $0.115 \mathrm{a}$ & $0.110 \mathrm{~b}$ & $148.48 \mathrm{~b}$ & $156.91 \mathrm{~b}$ & $61.00 \mathrm{a}$ & $56.00 \mathrm{a}$ \\
Turmeric Extract 2\% & $16.30 \mathrm{bc}$ & $16.20 \mathrm{c}$ & $0.115 \mathrm{a}$ & $0.110 \mathrm{~b}$ & $143.25 \mathrm{c}$ & $152.85 \mathrm{~b}$ & $50.40 \mathrm{c}$ & $49.50 \mathrm{~b}$ \\
Black Seed Oil 2\% & $15.40 \mathrm{de}$ & $15.70 \mathrm{~d}$ & $0.120 \mathrm{a}$ & $0.120 \mathrm{a}$ & $133.68 \mathrm{e}$ & $134.76 \mathrm{c}$ & $40.00 \mathrm{~d}$ & $41.50 \mathrm{c}$ \\
Onion Oil 2\% & $15.80 \mathrm{~cd}$ & $15.90 \mathrm{~cd}$ & $0.115 \mathrm{a}$ & $0.120 \mathrm{a}$ & $138.49 \mathrm{~d}$ & $134.75 \mathrm{c}$ & $56.00 \mathrm{~b}$ & $55.00 \mathrm{a}$ \\
Garlic Oil 2\% & $15.00 \mathrm{e}$ & $15.10 \mathrm{e}$ & $0.120 \mathrm{a}$ & $0.120 \mathrm{a}$ & $130.43 \mathrm{e}$ & $130.17 \mathrm{c}$ & $36.00 \mathrm{e}$ & $37.00 \mathrm{~d}$ \\
\hline
\end{tabular}

Means having the same letter (s) within the same column and row are not significantly different according to Duncan, $s$ multiple range test at $5 \%$ level of probability

Table (7): Effect of spraying some plant extracts and oils on sugars and total phenols of Naomi mango cv during 2017 \& 2018 seasons

\begin{tabular}{|c|c|c|c|c|c|c|c|c|}
\hline \multirow{3}{*}{ Treatment } & \multicolumn{6}{|c|}{ Sugars } & \multirow{2}{*}{\multicolumn{2}{|c|}{$\begin{array}{c}\text { Total Phenols } \\
\text { (mg/100 g fresh } \\
\text { weight) }\end{array}$}} \\
\hline & \multicolumn{2}{|c|}{ Total \% } & \multicolumn{2}{|c|}{ Reducing \% } & \multicolumn{2}{|c|}{ Non reducing \% } & & \\
\hline & 2017 & 2018 & 2017 & 2018 & 2017 & 2018 & 2017 & 2018 \\
\hline Control & $10.83 \mathrm{a}$ & $10.94 \mathrm{a}$ & $4.33 \mathrm{c}$ & $4.20 \mathrm{e}$ & $6.51 \mathrm{a}$ & $6.74 \mathrm{a}$ & $45.33 \mathrm{a}$ & $45.51 \mathrm{~b}$ \\
\hline Green Tea Extract 2\% & $10.63 \mathrm{a}$ & $10.60 \mathrm{~b}$ & $4.49 \mathrm{c}$ & $4.54 \mathrm{c}$ & $6.14 \mathrm{ab}$ & $6.06 \mathrm{~b}$ & $46.58 \mathrm{a}$ & $46.80 \mathrm{a}$ \\
\hline Turmeric Extract 2\% & $10.18 \mathrm{ab}$ & $10.13 \mathrm{~d}$ & $5.00 \mathrm{~b}$ & $5.00 \mathrm{~b}$ & $5.18 \mathrm{c}$ & $5.13 \mathrm{e}$ & $41.44 \mathrm{~b}$ & $41.30 \mathrm{~d}$ \\
\hline Black Seed Oil 2\% & $10.46 \mathrm{ab}$ & $10.40 \mathrm{c}$ & $5.02 \mathrm{~b}$ & $4.99 \mathrm{~b}$ & $5.44 \mathrm{bc}$ & $5.41 \mathrm{~d}$ & $40.01 \mathrm{c}$ & $41.00 \mathrm{e}$ \\
\hline Onion Oil 2\% & $10.37 \mathrm{ab}$ & $10.36 \mathrm{c}$ & $4.52 \mathrm{c}$ & $4.50 \mathrm{~d}$ & $5.86 \mathrm{abc}$ & $5.86 \mathrm{c}$ & $42.51 \mathrm{~b}$ & $42.25 \mathrm{c}$ \\
\hline Garlic Oil 2\% & $9.64 \mathrm{~b}$ & $9.66 \mathrm{e}$ & $5.33 \mathrm{a}$ & $5.28 \mathrm{a}$ & $4.31 \mathrm{~d}$ & $4.38 \mathrm{f}$ & $35.80 \mathrm{~d}$ & $36.15 \mathrm{f}$ \\
\hline
\end{tabular}

Means having the same letter (s) within the same column and row are not significantly different according to Duncan, $s$ multiple range test at $5 \%$ level of probability

Table (8): Effect of spraying some plant extracts and oils on enzymes activity of Naomi mango cv during 2017 \& 2018 seasons

\begin{tabular}{|c|c|c|c|c|}
\hline \multirow{2}{*}{ Treatment } & \multicolumn{2}{|c|}{ Polyphenol oxidase (O.D. unit $\times 103 / \mathrm{min} / \mathrm{g}$ ) } & \multicolumn{2}{|c|}{ Peroxidase (O.D. unit $\times$ 103/min $/ \mathrm{g}$ ) } \\
\hline & 2017 & 2018 & 2017 & 2018 \\
\hline Control & $1954.3 \mathrm{a}$ & $1942.0 \mathrm{a}$ & $180.5 \mathrm{a}$ & $173.0 \mathrm{a}$ \\
\hline Green Tea Extract $2 \%$ & $961.3 \mathrm{c}$ & $951.0 \mathrm{c}$ & $138.0 \mathrm{c}$ & $127.0 \mathrm{c}$ \\
\hline Turmeric Extract 2\% & $582.0 \mathrm{f}$ & $552.5 \mathrm{f}$ & $124.3 \mathrm{e}$ & $117.0 \mathrm{~d}$ \\
\hline Black Seed Oil 2\% & $1103.0 \mathrm{~b}$ & $1091.0 \mathrm{~b}$ & $157.0 \mathrm{~b}$ & $151.0 \mathrm{~b}$ \\
\hline Onion Oil 2\% & $913.7 \mathrm{~d}$ & $901.0 \mathrm{~d}$ & $136.0 \mathrm{c}$ & $124.0 \mathrm{c}$ \\
\hline Garlic Oil 2\% & $793.7 \mathrm{e}$ & $781.0 \mathrm{e}$ & $131.3 \mathrm{~d}$ & $127.0 \mathrm{c}$ \\
\hline
\end{tabular}

Means having the same letter (s) within the same column and row are not significantly different according to Duncan, $\mathrm{s}$ multiple range test at $5 \%$ level of probability 


\section{CONCLUSION}

Using foliar spray of plant extracts and oils improved the yield and fruit quality of Naomi mango cultivar and help in delay fruit ripening.

\section{REFERENCES}

Abd El-Rahman, M. M. A. and S. M. A. El-Masry (2012). Response of Valencia orange trees to foliar application of some vitamins, salicylic acid and turmeric extract. Minia J. of Agric. Res. \& Develop., 32(5): 1-17.

Ahemd, F. F., A. E. M. Mansour, M. A. A. Montassre, M. M. Merwad and E. A. M. Mostafa (2013). Response of Valencia orange trees to foliar application of Roselle, Turmeric and seaweed extracts. J. of Applied Sciences Res., 9(1): 960-964.

Ammon, H. and M. Wehle (1999). Pharmacology of Curcuma Longa. Planto Med., 57: 1-7.

Aroyeun, S. O. and C. O. Jayeola (2016). Effects of Green Tea Extracts on the Caffeine, Tannin, Total Polyphenolic Contents and Organoleptic Properties of Milk Chocolate. J Food Process Technol., 7: 579.

Association of Official Agricultural Chemists (2000). Official Methods of analysis $17^{\text {th }}$ Ed., A.O.A.C., Washington, D.C. U.S.A. pp. 490520.

Bhdwaj, R. L., L. K. Dhashora and S. Mukherjee (2010). Effect of neem leaf extract and benzyladenine on post harvest shelf life of orange (Citrus reticulata Blanco). J. Adv. Dev. Res., 1(1): 32-37.

Bravo, L. (1998). Polyphenols chemistry, dietary sources, metabolism, and nutritional significance. Nutr Rev., 56: 317-333.

Bruneton, J. (2001). Farmacogenosia. Zaragoza, Ed. Acriba, pp. 294-296.

Chawdhury, M. N. A., M. A. Rahim, K. M. Khalequzzaman, M. R. Humauan and M. M. Alam (2007). Effect of plant extracts and time of application on incidence of anthracnose, yield and quality of mango. Int. J. Sustain, Crop Prod., 2(5): 59-68.

Eid, M. H. Abd-allah, Safaa A. Nomier, M. M. Ibrahim and M. M. Gad (2018). Effect of some natural extracts, indolbutyric acid and Naphthalene acetic acid on rooting of picual olive cuttings. Zagazig j. Agric. Res., 45(1): 119-136.

El-Rokiek, G. K., G. M. Dawood, S. M. Sadak and M. E. L. El-Awadi (2019). The effect of the natural extracts of garlic or eucalyptus on the growth, yield and some chemical constituents in quinoa plants. Bulletin of the National Research Centre, 43: 1-7.

El-Sharony, T. F., S. F. El-Gioushy, O. A. Amin (2015). Effect of foliar application with algae and plant extracts on growth, yield and fruit quality of fruitful mango trees cv. Fagri Kalan. J. Horticulture, 2(4): 1-6.
El-Shayeb, N. S. A. (2009). Physiological studies on Oenothera biennis (Bio-fertilizer and plant extracts). Ph.D. Thesis, Hort. Dept. Fac. Agric., Benha Univ., Egypt.

El-Wasfy, M. M., F. A. Faissal and S. M. A. El-Masry (2013). Behaviour of Washington Novel Orange trees to foliar application of some plant extracts. Hortscience Journal of Suez Canal University, (1): 281-285.

Faissal F. A., M. Kh. Kamel and H. I. M. Ibrahim (2014). The Synergistic Effects of Using Plant Extracts and Salicylic Acid on Yield and Fruit Quality of Keitte Mango Trees. Stem Cell, 5(2): 30-39.

Ghosheh, O. A., A. A. Houdi and P. A. Crooks (1999). High performance liquid chromatographic analysis of the pharmacologically active quinones and related compounds in the oil of the black seed (Nigella sativa L.). J. Pharm. Biomed. Anal., 19: 757-762.

Habib, S. S., M. T. Wahdan, M. A. Bassal and E. M. Qaoudm (2004). Physiological studies on the Effect of paclobutrazol (Cultar) on mango trees. II-fruit drop, fruit retention, yield and fruit quality. J. Agri. Sci. Mansoura Univ., 29(5): 2769-2781.

Hosseinzadeh, H., S. Parvardeh, M. N. Asl, H. R. Sadeghnia and T. Ziaee (2007). Effect of thymoquinone and Nigella sativa seeds oil on lipid peroxidation level during global cerebral ischemia-reperfusion injury in rat hippocampus. Phytomedicine, 14: 621-7.

Jiménez-Cuesta, M. J., J. Cuquerella and J. M. Martínez-Jávega (1981). Determination of a color index for citrus fruit degreening. In Proc. of the International Society of Citriculture, 2: 750-753.

Kahramanoglu, İ. (2018). Black seed oil applications for the preservation of postharvest quality of 'wonderful' pomegranate under modified atmosphere packaging. Journal of Agricultural Science, 10(9): 87-94.

Kahramanoğlu, İ., M. Aktaş and S. GuÈnduÈz (2018). Effects of fludioxonil, propolis and black seed oil application on the postharvest quality of Wonderful pomegranate. PLoS ONE, 13(5): e0198411.

Lakshminarayana, S., N. V. Subhadva and W. Subramanyam (1970). Some aspects of developmental physiology of the mango fruit J. Hort. Sci., 45, 133-42.

McKay, D. L. and J. B. Blumberg (2002). The role of tea in human health update. J. Am. Coll. Nutrit., 21: 1-13.

Mohamed, A. Y. and H. H. Mohammed (2013). The synergistic effects of using turmeric with various nutrients on fruiting of Sewy Date palms. Hortscience J. of Suez Canal Univ., 1(1): 287-296.

MSTAT-C (1990). A microcomputer program for the design, management and analysis of agronomic research experiments, Michigan State University. 
Nergiz, C. and S. Otles (1993). Chemical composition of Nigella sativa L. seeds. Food Chem., 48: 259-261.

Obagwu, J., A. M. Emechebe and A. A. Abeoti (1997). Effect of extracts of Garlic (Allium sativum L.) bulb and Neem (Azadirachta indica Juss.) seed on the mycelia growth and sporulation of Colletortichum capsici (syd) Butler and Bibsy. J. of Agric. Tech., 5(1): 51-55.

Okigbo, B. N. and A. O. Emoghene (2003). Effect of leaf extracts of three plant species on Mycosphaerella fijiensis Morelet, the canal organism of black sigatoka disease of banana (Musa acuminate) Nigeria J. of Plant Prot., 20: 101-110.

Paik, S. and I. Chung (1997). Effect of medicinal plant extracts on apple storage disease. Korean J of Plant Pathology, 13: 57-62.

Parakash, L. and S. Majeed (2003). Mutlifunctional ingredients. The Nova Face of Natural C \&T, 118(11): 41-47.

Pons, L. I. (2003). Fotoproteccion Vegeta (II). Offarm, 22: 163-164.

Reddy, Y. V. and G. C. Srivastava (2003). Superoxide dismutase and peroxidase activities in ripening Mango (Mangifera indica L.) Fruits. Indian Journal of Plant Physiology, 8: 115119.

Rietveld, A. and S. Wiseman (2003). Antioxidant effects of tea: evidence from human clinical trials. The J. Nutrit, 133: 3285-3292.

Rocha Ribeiro, S. M., J. H. Queiroz, M. E. Lopes Ribeiro de Queiroz, F. M. Campos and H. M. Pinheiro Sant'ana (2007). Antioxidant in mango (Mangifera indica L.) pulp. Plant Foods for Human Nutrition (Dordrecht, Netherlands), 62(1): 13-17.

Samad, M., M. Sajid and I. Hussain (2019). Influence of herbal extract and storage duration on fruit quality of china lime. Horticult. Int. J., 3(3): $153-158$

Scalbert, A. and G. Williamson (2000). Dietary intake and bioavailability of polyphenols. J. Nutr. 130: 2073S-2085S.

Selvaraj, Y. and R. Kumar (1989). Studies on fruit softening enzyme and polyphenoloxidase activity in ripening mango (Mangifera indica L.) fruit. J. Fd. Sci. Technol., 26: 218-222.

Snedecor, G. W. and W. G. Cochran (1990). Statistical methods $\left(6^{\text {th }}\right.$ ed). The Iowa State. Univ.

Srimal, R. C. (1997). Turmeric a brief review of medicinal properties. Fitoterapia., 68(6): 483494.

Srivastava, A. K. and B. Lal (1997). Studies on biofungicidal properties of leaf extract of some plants. Ind phytopath, 50(3): 408-411.

Stahl, W., H. Van den Berg, J. Arthur, A. Bast and J. Dainly (2002). Bioavailability and metabolism. Mol Aspects Med, 23: 39-100.

Trejo-Márquez, M. A., G. Ramírez-Villatoro and N. A. Camacho de la Rosa (2010). Polyphenol oxidase and peroxidase activities in mangoes stored at chilling temperature. Acta hort., 864: 395.

Venkatesan, T. and C. Tamilmani (2010). Effect of ethrel on phenolic changes during ripening of offseason fruits of mango (Mangifera indica L. var. Neelum). Curr. Bot., 1(1): 22-28. 


\section{تأثير بعض المستخلصات والزيوت النباتية على محصول وجودة ثمار مانجو ناعومي}

\section{السبد مصطفى قاعود}

قسم البساتين - كلية الزر اعة ـ جامعة قناة السويس ـ مصر

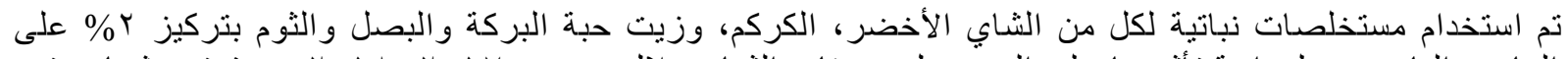

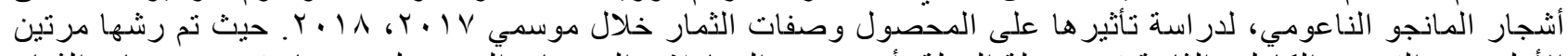

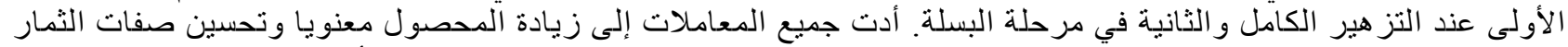

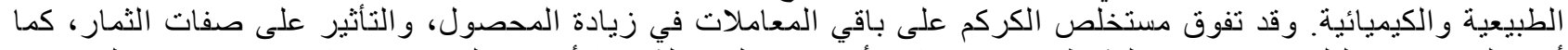

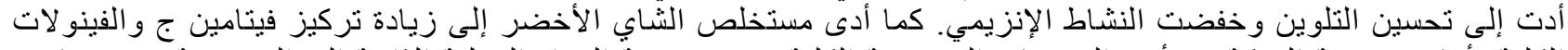

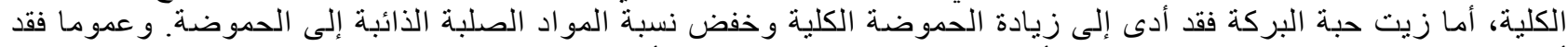

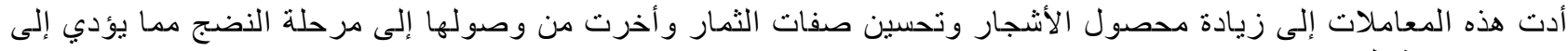
تحسين فرصة التسويق. 